\title{
Perception of IIIness, Coping Style, and Magical Ideation in Patients with Breast Cancer
}

\author{
(1) Yasemin KOÇYiĞiT,' (1) Ayşe Gökçen GÜNDOĞMUŞ, ${ }^{1}$ (i) Başaran DEMiR ${ }^{2}$ \\ 'Department of Mental Health and Diseases, University of Health Sciences, Diskapi Yildirim Beyazit Training and Research Hospital, \\ Ankara-Turkey \\ ${ }^{2}$ Department of Mental Health and Diseases, Hacettepe University, Ankara-Turkey
}

\begin{abstract}
OBJECTIVE
Breast cancer patients usually have psychological symptoms related with their perceptions of cancer. In our study, we aimed to investigate perception of illness, coping styles, and magical ideation of breast cancer patients, to compare their coping styles and magical ideation with healthy controls, and to investigate the relationships between these parameters.
\end{abstract}

\section{METHODS}

The study included 51 breast cancer patients and 79 people as control group. The Revised Illness Perception Questionnaire (IPQ-R) was given cancer patients and Coping Orientation to Problems Experienced Inventory and The Magical Ideation Scale (MIS) were given both patients and healthy controls.

\section{RESULTS}

IPQ-R personal control perception and treatment control mean scores were higher than the other subdimension scores. Personal attributions and luck have been reported as the primarily cause of illness by patients. MIS scores were higher in the control group than patients. Emotion-focused coping scores were significantly lower in the cancer group than control group. A significant positive correlation has been found between the emotion-focused coping and cognitive representations and causal attributions.

\section{CONCLUSION}

Understanding how patients perceive the disease, their causal attributions and coping styles provides useful information to psychiatrists in planning psychosocial interventions.

Keywords: Breast cancer; coping style; ilness perception; magical ideation; psychiatry.

Copyright $\odot$ 2021, Turkish Society for Radiation Oncology

\section{Introduction}

Breast cancer is the most common type of cancer in women and may to significant changes in the body that may cause death.[1] In cancer patients, psychological symptoms are often accompanied by physical symptoms. The perceptions of patients with cancer toward their illness are significant determinants of these psychological symptoms they often encounter[2,3] and the perceptions can be affected by several variables, such as age, life experiences, personality, beliefs, socioeconomic status, marital status, family history, the severity of illness, level of education, and clinical features of the illness.[4-12]

Perception of illness is indicative of an individual's judgments and beliefs about an illness.[13] The term is based on Leventhal's self-regulation theory and illness representation model.[14,15] According to self-regula- 
tion theory, when a person is undergo a health threat, internal stimuli (symptoms of illness), and external stimuli (being sick) produce cognitive and emotional reactions.[15]

Interventions based on the perception of illness in patients with chronic illnesses can reduce emotional distress.[6] Cultural background may also affect the beliefs and behaviors of patients regarding health and how they cope with illness.[16] Whatever illness is causing stress, the coping style adapted can promote effective management of the illness, and coping ability can improve with time.[17]

Immediately following the diagnosis of cancer, patients will ask themselves such questions as why me? what should I do? and why do I have cancer? and will struggle to make sense of the situation.[18,19] A cancer diagnosis can result in significant life changes, including the experience of stress, anxiety, and fear. Such emotions indicate that a patient needs to develop a coping strategy.[17] Just as a patient is unable to find an appropriate explanation for their cancer diagnosis, they will activate their own belief system.[20] When considering the causes of their illness, which is among the dimensions of the perception of illness, some cancer patients attribute their illness to such factors as chance.[21]

Thinking that an event is linked to another event by culturally unaccepted causes is known as magical ideation.[22] Although magical ideation is a significant feature in schizophrenia, schizotypy, delusional disorder, and obsessive-compulsive disorder[23] and has been investigated in somatoform disorder,[24] it has not been studied sufficiently in patients with medical illnesses, including cancer. It has been shown in various patient groups that understanding magical ideation may be beneficial in terms of increasing the diversity of therapeutic interventions, especially by identifying subgroups in which the use of imaginative techniques is effective.[24,25]

The present study aims to investigate the perception of illness, coping style and magical ideation in patients undergoing treatment for breast cancer, and compare coping style and magical ideation in patients with breast cancer and healthy controls. It was hypothesized that cancer patients who perceive their illness more positively are expected to use more functional coping mechanisms and cancer patients with a tendency for magical ideation will attribute the cause of their illness to chance, which will be associated with a decrease in the sense of control over their illness.

\section{Materials and Methods}

\section{Participants}

The present study included two groups. The breast cancer group consisted of patients with breast cancer that were presented to Diskapi Yildirim Beyazit Training and Research Hospital, Psychiatry Outpatient Clinic, Ankara, Turkey, between March 1, 2019, and September 1, 2019. The criteria for inclusion of patients were a diagnosis of breast cancer, female gender, age 18-65 years, and literacy. The criteria for the control group, which included healthy volunteers, were female gender, no chronic illnesses, age 18-65 years, literacy, and no active mental illness or admission. Individuals with a physical illness or limitation preventing being interviewed, a psychiatric or neurological disorder that may affect cognitive functions, and an active alcohol/substance use disorder were excluded from this study. This study included 130 participants. The study protocol was approved by the Ankara Diskapi Yildirim Beyazit Training and Research Hospital Ethics Committee (decision no. 65/15). All the participants provided written informed consent.

\section{Scales}

\section{Questionnaire for socio-demographic data}

This form was used to collect socio-demographic data, including age, gender, marital status, and level of education.

\section{The revised illness perception questionnaire (IPQ-R)}

This scale was developed by Weinman et al.[26] Armay et al.[27] reported that the Turkish version was valid and reliable for use in cancer patients in Turkey. The scale consists of three subscales:

\section{Illness identity}

This subscale includes questions about 14 common symptoms experienced since the beginning of the illness and whether the respondent has found any connection to the illness.

\section{Cognitive representations about illness}

This subscale includes 38 items regarding opinions about illness. Items are answered using a 5-point Likert-type scale. This subscale includes seven sub-dimensions: Personal controllability, treatment controllability, acute/chronic timeline, cyclical timeline, coherence, consequences, and emotional representations.

\section{Causal attributions}

This subscale includes 18 items concerning a person's thoughts about the possible causes of an illness. Items 
are answered using a 5-point Likert-type scale. The subscale consists of four sub-dimensions: Psychological attributions, risk factor attributions, immune attributions, and chance attributions. At the end of the scale, respondents are requested to write down three factors that they regard as the most important cause of their illness. The validity and reliability study of the Turkish version performed by Armay et al.[27] identified five sub-dimensions, not four as in the original.

\section{Coping Orientation to Problems Experienced Inven- tory (COPE) inventory}

The scale was developed by Carver et al.[28] The Turkish version was reported to be valid and reliable by Ağargün et al.[29] This self-report scale includes 60 items that are answered, as follows: 1 . I would never do such a thing; 2. I rarely do such a thing; 3 . I do this moderately; and 4. I mostly do this. The scale has 15 subscales that are grouped and provide scores for problem-focused, emotion-focused, and non-functional coping styles.

\section{The Magical Ideation Scale (MIS)}

This 30 -item scale was designed to evaluate magical ideation. The items are answered as true or false. Eckblad and Chapman[22] developed the scale to predict future psychotic symptoms in young adults. Most of the scale's items include terminology based on modifications of Schneider's first-order symptoms that can indicate susceptibility to psychosis. The Turkish version was reported to be valid and reliable by Atbaşoğlu et al.,[30] with cutoff scores of 21 for males and 23 for females. Higher total scores indicate a greater tendency for magical ideation.

\section{Statistical Analysis}

Statistical analysis was performed using IBM SPSS Statistics for Windowsv.21.0 (IBM Corp., Armonk, $\mathrm{NY}$ ). As the assumption of normality was fulfilled, parametric tests were used for all analyses. Socio-demographic data were evaluated using descriptive analysis methods. For between-group comparisons, the t-test was used and to control for the effect of independent variables on dependent variables, the ANCOVA method was used. Pearson's correlation analysis was used to investigate the relationships between dependent variables.

\section{Results}

This study included 130 participants: 51 participants in the breast cancer group and 79 participants in the control group. Participant socio-demographic data are shown in Table 1 . There was a significant difference between the two groups in age $(t=11.297, \mathrm{p}<0.001)$ and years of education $(t=-5.621, p<0.001)$. Mean age in the breast cancer group (54.06 \pm 9.97 years) was significantly higher than in the control group $(33.85 \pm 9.45$ years). Mean years of education in the control group (10.71 \pm 3.78 years) were significantly higher than in the breast cancer group ( $7.08 \pm 3.47$ years).

In all, $92 \%$ of patients with breast cancer reported that they were informed about their illness. According to IPQ-R scores in the breast cancer group, from the onset of the illness the most common symptoms were fatigue $(33.8 \%)$, loss of strength $(26.9 \%)$, and sleep disturbance $(23.1 \%)$, of which fatigue and loss

Table 1 Socio-demographic characteristics of the participants

\begin{tabular}{|c|c|c|c|c|c|c|}
\hline \multirow[t]{2}{*}{ Variable } & \multicolumn{2}{|c|}{$\begin{array}{c}\text { Breast cancer } \\
\text { group } \\
(n=51)\end{array}$} & \multicolumn{2}{|c|}{$\begin{array}{l}\text { Control group } \\
\quad(n=79)\end{array}$} & \multicolumn{2}{|c|}{$\begin{array}{c}\text { Total } \\
(n=130)\end{array}$} \\
\hline & Mean & SD & Mean & SD & Mean & SD \\
\hline Age, years & 54.06 & 9.97 & 33.85 & 9.46 & 41.49 & 13.76 \\
\hline \multirow[t]{2}{*}{ Years of education } & 7.08 & 3.47 & 10.71 & 3.78 & 9.28 & 4.06 \\
\hline & $\mathbf{n}$ & $\%$ & $\mathbf{n}$ & $\%$ & $\mathbf{n}$ & $\%$ \\
\hline \multicolumn{7}{|l|}{ Level of education } \\
\hline Literate & 3 & 100 & 0 & 0 & 3 & 100 \\
\hline Primary school & 30 & 66.7 & 15 & 33.3 & 45 & 100 \\
\hline Middle school & 5 & 23.8 & 16 & 76.2 & 21 & 100 \\
\hline High school & 9 & 23.7 & 29 & 76.3 & 38 & 100 \\
\hline University & 4 & 17.4 & 19 & 82.6 & 23 & 100 \\
\hline Duration of illness, years & 5.46 & 3.36 & - & & & \\
\hline
\end{tabular}


of strength were most commonly associated with cancer. In the breast cancer group, mean IPQ-R perception of personal control and treatment control sub-dimension scores were higher than for the scale's other sub-dimensions (Table 2). In the breast cancer group, IPQ-R causal attributions subscale personal attributes (stress or anxiety, my attitude, personality, and emotional state) and luck sub-dimension scores were higher than other causal attribution sub-dimension scores.

MIS total scores were below the cutoff in both the breast cancer and control groups, although the scores were significantly lower in the breast cancer group $(\mathrm{p}=0.020)$ (Table 3). COPE Inventory emotion-focused coping scores were significantly lower in the breast cancer group than in the control group $(p=0.016)$,

\begin{tabular}{|c|c|c|}
\hline IPQ-R subscales & Mean & SD \\
\hline \multirow{2}{*}{\multicolumn{3}{|c|}{$\begin{array}{l}\text { Cognitive representations } \\
\text { about the illness }\end{array}$}} \\
\hline & & \\
\hline Acute/chronic timeline & 2.51 & 0.86 \\
\hline Consequences & 2.93 & 0.75 \\
\hline Personal control & 3.45 & 0.56 \\
\hline Treatment control & 4.04 & 0.78 \\
\hline Coherence & 2.27 & 0.71 \\
\hline Cyclical timeline & 2.32 & 0.72 \\
\hline Emotional representations & 3.06 & 0.94 \\
\hline \multicolumn{3}{|l|}{ Causal attributions } \\
\hline Personal attributions & 2.87 & 0.93 \\
\hline External attributions & 2.1 & 0.86 \\
\hline Life-style attributions & 1.97 & 0.98 \\
\hline Uncontrollable factors & 2.27 & 0.97 \\
\hline Luck & 2.5 & 1.4 \\
\hline
\end{tabular}

IPQ-R: Revised illness perception questionnaire but there was not a significant difference between the groups concerning problem-focused coping and nonfunctional coping (Table 3).

As the two groups differed concerning education and age, ANCOVA analysis was performed to compare the groups after removing the effects of these parameters on the study scales' scores. ANCOVA showed that the group-education level common effect was not significant on the MIS score $\left(\mathrm{F}_{(1-126)}=0.034, \mathrm{p}=0.853\right)$, COPE Inventory problem-focused coping score $\left(\mathrm{F}_{(1-125)}=3.157\right.$, $\mathrm{p}=0.078)$, COPE Inventory emotion-focused coping score $(\mathrm{F}(1-125)=3.603, \mathrm{p}=0.060)$, or COPE Inventory non-functional coping score $\left(\mathrm{F}_{(1-126)}=0.556, \mathrm{p}=0.457\right)$. According to the level of education in the two groups $\left(\mathrm{F}_{(1-127)}=6.190, \mathrm{p}<0.05\right)$, there was a significant difference only concerning the corrected MIS score. According to the results of the Bonferroni test, MIS scores were significantly lower in the breast cancer group (mean $=6.33$ ) than in the control group (mean=8.23).

According to ANCOVA analysis of age, the groupage joint effect was not significant for the MIS score $\left(\mathrm{F}_{(1-123)}=1.147, \mathrm{p}=0.286\right)$, or the COPE Inventory problem-focused coping score $\left(\mathrm{F}_{(1-122)}=0.361, \mathrm{p}=0.549\right)$, COPE Inventory emotion-focused coping score $\left(\mathrm{F}_{(1-}\right.$ ${ }_{122)}=1.031, \mathrm{p}=0.312$ ), and COPE Inventory non-functional coping score $\left(\mathrm{F}_{(1-123)}=0.003, \mathrm{p}=0.956\right)$. In addition, there was not a significant difference in MIS total scores $\left(\mathrm{F}_{(1-124)}=2.565, \mathrm{p}=0.112\right)$, COPE Inventory problem-focused coping scores $\left(\mathrm{F}_{(1-123)}=0.138, \mathrm{p}=0.711\right)$, COPE Inventory emotion-focused coping scores $\left(\mathrm{F}_{(1-}\right.$ ${ }_{123)}=0.910, \mathrm{p}=0.342$ ), or COPE Inventory non-functional coping scores $\left(\mathrm{F}_{(1-124)}=3.609, \mathrm{p}=0.060\right)$ between the two groups after adjusting for age.

Finally, the relationships between COPE Inventory sub-dimension scores, IPQ-R subscale scores, and MIS scores are shown in Table 4 . There was a significant negative correlation between the COPE Inventory problem-

Table 3 Comparison of magical ideation and COPE inventory scores between the breast cancer and control groups

\begin{tabular}{|c|c|c|c|c|c|c|c|}
\hline Scales & Group & $\mathbf{n}$ & Mean & SD & Df & $\mathbf{T}$ & $\mathbf{p}$ \\
\hline \multirow[t]{2}{*}{ Magical ideation scale } & Breast cancer group & 51 & 6.49 & 3.9 & 104.3 & $-2.368^{*}$ & 0.020 \\
\hline & Control group & 79 & 8.13 & 3.77 & & & \\
\hline \multirow[t]{2}{*}{ COPE inventory problem-focused coping } & Breast cancer group & 50 & 7.17 & 1.01 & 120.16 & 0.427 & 0.670 \\
\hline & Control group & 79 & 8.96 & 1.01 & & & \\
\hline \multirow[t]{2}{*}{ COPE inventory emotion-focused coping } & Breast cancer group & 50 & 5.79 & 0.82 & 126.99 & $2.437^{*}$ & 0.016 \\
\hline & Control group & 79 & 9.1 & 1.02 & & & \\
\hline \multirow[t]{2}{*}{ COPE inventory non-functional coping } & Breast cancer group & 51 & 42.22 & 7.29 & 109.12 & 1.585 & 0.116 \\
\hline & Control group & 79 & 40.11 & 7.51 & & & \\
\hline
\end{tabular}

COPE: Coping orientation to problems experienced; Df: Degree of freedom; T: t-test statistics; *: Significant, $\mathrm{p}<0.05$ 
Table 4 The relationship between COPE inventory subscale scores, MIS score, and IPQ-R score in the breast cancer group

\begin{tabular}{|c|c|c|c|c|}
\hline & $\begin{array}{l}\text { COPE inventory } \\
\text { problem-focused } \\
\text { coping scale }\end{array}$ & $\begin{array}{l}\text { COPE inventory } \\
\text { emotion-focused } \\
\text { coping }\end{array}$ & $\begin{array}{l}\text { COPE inventory } \\
\text { non-functional } \\
\text { coping }\end{array}$ & $\begin{array}{c}\text { Magical } \\
\text { ideation } \\
\text { scale }\end{array}$ \\
\hline \multicolumn{5}{|c|}{ IPQ-R Cognitive representations about the illness } \\
\hline Acute/chronic timeline & $-0.356^{*}$ & 0.040 & -0.001 & 0.094 \\
\hline Consequences & 0.165 & $0.351^{*}$ & 0.086 & -0.017 \\
\hline Personal control & 0.219 & 0.011 & -0.124 & -0.161 \\
\hline Treatment control & 0.043 & -0.067 & -0.266 & -0.241 \\
\hline Coherence & 0.027 & -0.092 & $-0.302^{*}$ & -0.003 \\
\hline Cyclical timeline & 0.113 & 0.090 & 0.129 & 0.146 \\
\hline Emotional representations & 0.108 & 0.123 & 0.110 & 0.142 \\
\hline \multicolumn{5}{|l|}{ IPQ-R Causal attributions } \\
\hline Personal attribution & 0.134 & 0.111 & 0.112 & -0.086 \\
\hline External attribution & 0.149 & 0.122 & 0.129 & 0.088 \\
\hline Life style & 0.143 & 0.093 & 0.240 & 0.141 \\
\hline Uncontrolled & -0.110 & -0.127 & 0.219 & 0.070 \\
\hline Luck & 0.129 & $0.287^{*}$ & 0.208 & 0.163 \\
\hline MIS & 0.241 & 0.186 & 0.236 & 1 \\
\hline
\end{tabular}

COPE: Coping orientation to problems experienced; MIS: Magical ideation scale; IPQ-R: Revised illness perception questionnaire; *: Significant, $\mathrm{p}<0.05$

focused coping score and the IPQ-R cognitive representations about illness subscale and its acute/chronic timeline sub-dimension scores $(\mathrm{r}=-0.356, \mathrm{p}<0.05)$. There was a significant positive correlation between the COPE Inventory emotion-focused coping score and the IPQ-R cognitive representations about illness subscale score $(\mathrm{r}=0.351, \mathrm{p}<0.05)$ and IPQ- $\mathrm{R}$ causal attributions luck sub-dimension score $(\mathrm{r}=0.287, \mathrm{p}<0.05)$. There was a significant negative correlation between the COPE Inventory non-functional coping score and the IPQ-R coherence subscale score $(r=-0.302, p<0.05)$. There were not any significant relationships between the three study scales' other subscale scores.

\section{Discussion}

The present study aims to analyze illness perception, coping style, and magical ideation in patients with breast cancer and determine if there is a relationship between magical ideation, and coping style and illness perception. An additional aim is to compare the coping style and magical ideation in patients with breast cancer and healthy controls.

Fatigue is the most common symptom in cancer patients, affecting $48-64 \%$ of patients, negatively affecting functionality, and quality of life.[31-33] In the present study, $33.8 \%$ of the patients experienced fatigue, which was commonly associated with cancer, according to the IPQ-R symptoms of illness subscale. In all, $28.5 \%$ of the patients attributed their fatigue to breast cancer.
IPQ-R personal control perception and treatment control mean scores were higher than the other sub-dimension scores in the breast cancer group. The personal control perception sub-dimension score is indicative of an individual's perception of control over the duration, course, and treatment of an illness and evaluates beliefs about an individual's power to influence the course of illness. The treatment control sub-dimension of IPQ- $R$ evaluates an individual's beliefs about the treatment of illness and higher scores indicate a greater belief that illness can be controlled with treatment.[2] Many studies reported that an individual believing they have personal and treatment control over an illness is associated with adaptive coping styles.[34] Illness perception differs according to culture, and there is a relationship between the perception of control and the level of anxiety.

The diagnosis of cancer results in significant life changes, and patients begin to have existential questions and attempt to regain control of their lives.[35] The high perception of personal control and treatment control scores in the present study's breast cancer group can be considered in this context. In the present study, the patients' IPQ-R understanding of the illness scores was lower than the other IPQ-R sub-dimension scores. According to the literature, cancer patients are not sufficiently informed about their illness.[36] In the present study, $92 \%$ of the patients reported that they were informed about their illness, but not adequately.

In the present study, the patients with breast cancer primarily reported personal attributions and luck 
as the cause of their illness. In addition to individual and environmental attributes, cultural attributes also play a crucial role in the perception of illness. $[37,38]$ In agreement with the present findings, it was reported earlier that in Turkish society that illness was commonly attributed to stress.[37] Based on the literature, illness is often attributed to psychological causes, such as stress, which is an important focus of research because identifying causes of diseases that are modifiable can affect an individual's attitude after diagnosis. [39] On the other hand, attributing illness to luck may lead to negative perceptions and attitudes towards illness. [24,39]

Coping styles can be categorized as problem-focused and emotion-focused.[40] Individuals with a problem-focused coping style focus directly on problems related to an illness, using strategies aimed at themselves and the environment. Emotion-focused coping is characterized by dealing with the emotional consequences of illness and emerges when an individual determines that there is nothing to do in the face of a life-threatening illness.[41] This type of coping style primarily targets reducing the tension created by the illness process.[42] In the present study, patients with breast cancer used emotion-focused coping less frequently than the controls, but the two groups did not differ concerning other coping styles. It was reported that there was a relationship between coping style and level of education in cancer patients,[43] and as the present study observed a difference in the level of education between the breast cancer and controls groups, it was thought that it might affect the other findings; however, such an effect was not noted.

Magical ideation can be encountered in schizophrenia, schizotypy, delusional disorder, and obsessivecompulsive disorder, and some studies reported that magical ideation could manifest as paranormal beliefs in those with stress- and trauma-related disorders. $[44,45]$ In recent years, magical ideation has also been studied in somatoform disorders. [24] Magical ideation and paranormal beliefs may cause patients to misunderstand the cause of the disease.[22] In the present study, it was expected that due to illness-related stress, magical ideation would be more common in the breast cancer group than in the control group; however, in contrast to this assumption, magical ideation scores were below the cutoff in both groups, although the scores were higher in the control group. As the MIS used in the present study was developed to predict future psychotic episodes, especially in young adults,[30] it might be that the lower mean age in the control group accounted for this difference. However, further analysis showed that age did not affect. In the present study, none of the participants had a score above the MIS cutoff. Further research is needed to more clearly discern if there are any differences in magical ideation between patients with breast cancer and healthy controls.

The present study also investigated the relationship between magical ideation, coping style and perception of the illness in patients with breast cancer. An individual's perception of illness strongly affects their coping style.[46] In the present study, patients that perceived their illness to be chronic were less likely to employ a problem-focused coping style. The literature emphasizes that the perception of the timeline of illness (cyclical or acute/chronic), which is measured by the IPQ- $R$ cognitive representations about illness subscale, causes negative perceptions that induce patients to develop an emotion-focused coping style, can predict post-treatment depression, has a significant effect on adverse psychological consequences of an illness, and can change over time.[34] In the present study, patients were more likely to adopt an emotion-focused coping style if they perceived the outcome of their illness more negatively and considered that luck was a causative factor. This finding is consistent with the results of earlier studies that reported a connection between negative perception of the outcome of an illness and a passive and non-functional coping style.[5,47] Patients with breast cancer that attribute their illness to luck are more likely to use a non-adaptive coping style than patients that attribute their illness to modifiable factors. [39]

The relationship between magical ideation and illness perception was also investigated in the present study. It was reported that those with a high degree of magical ideation were highly likely to attribute the cause of an illness to luck;[24] however, in the present study there was not a relationship between the perception that luck was the cause of breast cancer and magical ideation. As the precise role of magical ideation in the perception of illness among those with serious illnesses, such as chronic illnesses and cancer, is as yet unknown and has not been sufficiently studied, additional larger-scale research is warranted.

\section{Limitations}

The present study has a few limitations. The cross-sectional nature of the present study makes it difficult to show causality. Differences in disease stage and treatment between the patients might have affected the patients' perceptions of the disease differently. In ad- 
dition, the patients with breast cancer were not evaluated for psychopathology, which may affect patients' perception of illness.

\section{Conclusion}

Understanding how cancer patients perceive the illness process, what they attribute their illness to, and what coping style they use can aid clinicians in helping them acquire a positive mindset concerning the control and treatment of the disease, to make sense of the illness process with a healthy perspective, and to cope appropriately and adequately. Additional relevant research is needed for the development of effective psychological interventions for use by consulting psychiatrists treating patients with breast cancer.

Peer-review: Externally peer-reviewed.

Conflict of Interest: All authors declared no conflict of interest.

Ethics Committee Approval: The study was approved by the University of Health Sciences, Ankara Diskapi Yildirim Beyazit Training and Research Hospital Clinical Research Ethics Committee (No: 65/15, Date: 18/06/2019).

Financial Support: None declared.

Authorship contributions: Concept - Y.K., B.D., A.G.G.; Design - Y.K., B.D., A.G.G.; Supervision - Y.K., B.D., A.G.G.; Funding - Y.K., A.G.G.; Materials - Y.K., A.G.G.; Data collection and/or processing - Y.K., A.G.G.; Data analysis and/ or interpretation - Y.K., B.D., A.G.G.; Literature search Y.K., B.D., A.G.G.; Writing - Y.K., B.D., A.G.G.; Critical review - Y.K., B.D., A.G.G.

\section{References}

1. Balon J, Wehrwein TC. Cancer of the breast. In: Moore-Higgs, GJ, editor. Women and Cancer. A Gynecologic Oncology Nursing Perspective. $2^{\text {nd }}$ ed. United States: Jones and Bartlett Publishers; 2000. p. 318-55.

2. Rozema H, Vollink T, Lechner L. The role of illness representations in coping and health of women treated for breast cancer. Psycho Oncol 2009;18(8):849-57.

3. Moss Morris R, Weinman J, Petrie KJ, Horn R, Cameron LD, Buick D. The revised illness perception questionnaire (IPQR). Psychol Health 2002;17(1):1-16.

4. Postolica R, Iorga M, Petrariu F D, Azoicai D. Cognitive behavioral coping, illness perception and family adaptability in oncological women with a family history of cancer. BioMed Res Int 2007;3:1-11.
5. Hopman P, Rijken M. Illness perceptions of cancer women: Relationships with illness characteristics and coping. Psycho Oncol 2015;24(1):11-8.

6. McCorry NK, Dempster M, Quinn J, Hogg A, Newell J, Moore M, et al. Illness perception clusters at diagnosis predict psychological distress among women with breast cancer at 6 months post diagnosis. J Psycho Oncol 2013;22(3):692-8.

7. Nam S, Chesla C, Stotts NA, Kroon L, Janson SL. Barriers to diabetes management: Patient and provider factors. Diabet Res Clin Pract 2011;93(1):1-9.

8. Harvey J, Lawson V. The importance of health belief models in determining self-care behaviour in diabetes. Diabet Med 2009;26(1):5-13.

9. Kayaniyil S, Ardern CI, Winstanley J, Parsons C, Brister S, Oh P, et al. Degree and correlates of cardiac knowledge and awareness among cardiac in women. Patient Educ Couns 2009;75(1):99-107.

10. Gosse CS. Illness Representation and Glycemic Control in Women With Type 2 Diabetes Mellitus (Dissertation). Columbus: Ohio State University; 2007.

11. Broadbent E, Petrie KJ, Main J, Weinman J. The brief illness perception questionnaire. J Psychosom Res 2006;60(6):631-7.

12. Anagnostopoulos F, Spanea E. Assessing illness representations of breast cancer: A comparison of women with healthy and benign controls. J Psychosom Res 2005;58(4):327-34.

13. Karabulutlu E, Karaman S. Kanser hastalarinda hastalik algisinin değerlendirilmesi. J Health Sci and Prof 2015;2(3):271-84.

14. Leventhal H, Brissette I, Leventhal EA. The commonsense model of self-regulation of health and illness. In: Cameron LD, Leventhal H, editors. The Self-regulation of Health and Illness Behavior. Ch. 3. London: Routledge; 2003. p. 42-65.

15. Leventhal H, Meyer D, Nerenz D. The common sense representation of illness danger. In: Rachman S, editor. Contributions to Medical Psicology. New York: Pergamon Press; 1980. p. 17-30.

16. Attari SM, Ozgoli G, Solhi M, AlaviMajd H. Study of relationship between illness perception and delay in seeking help for breast cancer patients based on Leventhal's self regulation model. Asian Pac J Cancer Prev 2016;17:167-74.

17. Silva AV, Zandonade E, Amorim MH. Anxiety and coping in women with breast cancer in chemotherapy. Rev Lat Am Enfermagem 2017;25:e2891.

18. Kelley HH, Michela JL. Attribution theory and research. Annu Rev Psychol 1980;31:457-501.

19. Kleinman A. The Illness Narratives: Suffering, Healing and the Human Condition. New York: Harper and Row; 1988.

20. Gonzalez P, Lim JW, Wang-Letzkus M, Flores KF, Allen 
KM, Castañeda SF, et al. Breast cancer cause beliefs: Chinese, Korean, and Mexican American breast cancer survivors. West J Nurs Res 2015;37(8):1081-1099.

21. Vetsch CE, Wakefield EL, Doolan C, Signorelli BM, McGill L, Moore P, et al. Why us? Causal attributions of childhood cancer survivors, survivors' parents and community comparisons-a mixed methods analysis. Acta Oncol 2019;58(2):209-17.

22. Eckblad M, Chapman LJ. Magical ideation as an indicator of schizotypy. J Consul Clin Psychol 1983;51(2):215.

23. Peters ER, Joseph SA, Garety PA. Measurement of delusional ideation in the normal population: Introducing the PDI (Peters et al. Delusions Inventory). Schizophr Bull 1999;25(3):553-76.

24. Hausteiner-Wiehle C, Sokollu F. Magical thinking in somatoform disorders: An exploratory study among patients with suspected allergies. Psychopathology 2011;44(5):283-8.

25. Miller V, Whorwell PJ. Hypnotherapy for functional gastrointestinal disorders: A review. Int J Clin Exp Hypn 2009;57(3):279-92.

26. Weinman J, Petrie KJ, Moss-Morris R. The illness perception questionnaire: A new method for assessing the cognitive representation of illness. Psychol Health 1996;11(3):431-45.

27. Armay Z, Özkan M, Kocaman N, Özkan S. Hastalık algisi ölçeğinin kanser hastalarinda türkçe geçerlik ve güvenirlik çalişmasi. Klinik Psikiyatri 2007;10(4):192200.

28. Carver CS, Scheier MF, Weintraub JK. Assessing coping strategies: A theoretically based approach. J Pers Soc Psychol 1989;56:267-83.

29. Ağargün MY, Beşiroğlu L, Kıran ÜK, Özer ÖA, Kara H. COPE (Başa Çıkma Tutumlarını Değerlendirme Ölçeği): Psikometrik özelliklere ilişkin bir ön çalışma. Anadolu Psikiyatri Derg 2005;6:221-6.

30. Atbaşoğlu EC, Kalaycıŏglu C, Nalçacı E. Büyüsel Düşünce Ölçeğinin Türkçe formunun üniversite öğrencilerindeki geçerlik ve güvenilirliği. Turk Psikiyatri Derg, 2003;14:31-41.

31. Kayır G. Illness Perception of Oncology Patients and Their Ways to Deal With Stress. İstanbul, Türkiye: Istanbul University Institute of Health Sciences; 2014.

32. Kayı̧ A. Illness Perception and Hopelessness Levels in Cancer Patients. İstanbul, Türkiye: Institude of Medical Sciences, Haliç University; 2009.

33. Rüffer JU, Flechtner H, Tralls P, Josting A, Sieber M, Lathan B, et al. Fatigue in long term survivors of Hodgkin's lymphoma; a report from the German Hodgkin lymphoma study group (GHSG). Eur J
Cancer 2003;39(15):2179-806.

34. Aksan AT, Gizir CA. An assessment of the relationships among illness representations, coping, anxiety and depression levels of women diagnosed with breast cancer. Türk Psikolojik Danışma Rehberlik Dergisi 2019;9(54):623-58.

35. Bağ B. Long term psychosocial problems in cancer patients. Curr App Psychiatry 2013;5(1):109-26.

36. Kocaman N, Kutlu Y, Özkan M, Özkan S. Predictors of psychosocial adjustment in people with physical illness. Clin J Oncol Nurs 2007;16:6-16.

37. Özdemir A. Kanserli Hastalarda Hastalık Algısı ve Anksiyete Düzeyi Arasındaki İlişkinin Belirlenmesi. İnönü: İnönü Üniversitesi, Sağlık Bilimleri Enstitüsü, Hemşirelik Anabilim Dalı İç Hastalıkları Hemşireliği Programı Yüksek Lisans Tezi; 2016.

38. Yusuf S, Okuwa M, Irwan M, Rassa S, Laitung B, Thalib A, et al. Prevalence and risk factor of diabetic foot ulcers in a regional hospital, Eastern Indonesia. Open J Nurs 2016;6:1-10.

39. Peuker AC, Armiliato MJ, de Souza LV, de Castro EK. Causal attribution among women with breast cancer. Psicol Refl Crít 2016;29(1):1-6.

40. Folkman S, Lazarus RS. An analysis of coping in a middle-aged community sample. J Health Soc Behav 1980;21:219-39.

41. Lazarus RS, Folkman S. Stress, Appraisal, and Coping. New York: Springer Publishing; 1984.

42. Rohde P, Lewinshon TM, Tilson M, Seeley J. Dimensionality of coping and its relation to depression. J Pers Soc Psychol 1990;58:499-511.

43. Geyikci R, Cakmak S, Demirkol ME, Uguz S. Correlation of anxiety and depression levels with attitudes towards coping with illness and socio demographic characteristics in patients with a diagnosis of breast cancer. Dusunen Adam J Psychiatr and Neurolog Sci 2018;31:246-57.

44. Keinan G. The effects of stress and desire for control on superstitious behavior. Pers Soc Psychol Bull 2002;28:102-8.

45. Irwin HJ. Paranormal belief and proneness to dissociation. Psychol Rep 1994;75:1344-6.

46. Cameron LD, Jago L. Emotion regulation interventions: A common-sense model approach. $\mathrm{Br} \mathrm{J}$ Health Psychol 2008;13:215-21.

47. Fischer MJ, Wiesenhaan ME, Heijer AD, Kleijn WC, Nortier JW, Kaptein AA. From despair to hope: A longitudinal study of illness perceptions and coping in a psycho-educational group intervention for women with breast cancer. Br J Health Psychol 2013;18(3):526-45. 